Prace Komisji Geografii Komunikacji PTG Transport Geography Papers of Polish Gonikg

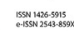
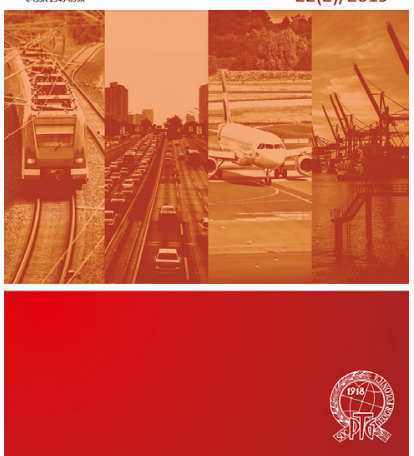

\section{Prace Komisji Geografii Komunikacji PTG}

$2019,22(2), 63-73$

DOI 10.4467/2543859XPKG.19.011.11151

\title{
REGIONALNE PORTY LOTNICZE W EUROPIE ŚRODKOWO-WSCHODNIEJ PO LIBERALIZACJI RYNKU TRANSPORTU LOTNICZEGO
}

\author{
Regional airports in Central and Eastern Europe after the liberalization \\ of the aviation market
}

\section{Edyta Pijet-Migoń}

Instytut Turystyki, Wyższa Szkoła Bankowa we Wrocławiu, Fabryczna 29-31, 53-609 Wrocław

e-mail: edyta.migon@wsb.wroclaw.pl

\section{Cytacja:}

Pijet-Migoń E., 2019, Regionalne porty lotnicze w Europie Środkowo-Wschodniej po liberalizacji rynku transportu lotniczego, Prace Komisji Geografii Komunikacji PTG, 22(2), 63-73.

Streszczenie: Zmiany polityczne i ekonomiczne w Europie Środkowo-Wschodniej wpłynęły znacząco na rozwój transportu lotniczego na tym obszarze. W większości państw najistotniejszym czynnikiem zmian była liberalizacja rynku transportu lotniczego. W przypadku portów lotniczych wschodniej części Niemiec największe zmiany w wielkości ruchu pasażerskiego nastąpiły bezpośrednio po zjednoczeniu NRD i RFN, zakończenie procesu liberalizacji w Europie Zachodniej nie miało już tak dużego wpływu. Aktywizacja portów regionalnych była bardzo często związana z ekspansją przewoźników niskokosztowych, którzy aktualnie w większości portów regionalnych mają dominujący udział w strukturze przewozów. Największy rozwój portów regionalnych nastąpił w największych nowych państwach UE - w Polsce i Rumunii. Szczególny rozwój nastąpił w portach w Krakowie, Gdańsku, Katowicach, Wrocławiu, Cluj-Napoca, Timişoarze i laşi. W przypadku mniejszych państw duży wzrost liczby pasażerów zanotowały porty w Kownie, Palandze i Debreczynie. Nie wszystkie porty regionalne rozwinęły się zgodnie z prognozami. W przypadku kilku portów duże inwestycje infrastrukturalne można uznać za nietrafione.

Słowa kluczowe: transport lotniczy, porty regionalne, linie niskokosztowe

\begin{abstract}
Political and economic changes in Central and Eastern Europe have had dramatic influence on air transportation market and its growth. In new European Union member countries liberalization of the market was the crucial factor, but in the eastern part of Germany, previously German Democratic Republic, the process of reunification of the country was the most important and hence, major changes and growths were of an earlier date. The implementation of the Third Liberalization Package in Western Europe, which occurred afterwards, was not so visible. The expansion of low cost carriers brought changes at almost all regional airports. Nowadays LCCs have a dominant position or even monopoly in smaller airports. Regional airports boomed especially in Poland and Romania, the most successful ones being Kraków, Gdańsk, Katowice, Wrocław, Cluj-Napoca, Timişoara and laşi. In the case of smaller countries the number of passengers increased significantly in Kaunas, Palanga and Debrecen. Not all airports have developed according to the forecasts. Substantial investments in infrastructure of some airports can be perceived as misguided.
\end{abstract}

Key words: air transport, regional airports, low cost carriers 


\section{Wprowadzenie}

W ostatnich dwóch dekadach rynek transportu lotniczego w Europie Środkowo-Wschodniej bardzo istotnie się zmienił. Do najbardziej widocznych zmian należą wzrost liczby pasażerów, rozwój sieci połączeń, powstanie nowych przedsiębiorstw lotniczych, ale również wzrost znaczenia portów regionalnych, rozwój infrastruktury lotniczej, zmiany funkcji wielu dawnych portów wojskowych na cywilną i rozbudowa lub nawet budowa nowych portów lotniczych. Na zmiany te wpływ miały zarówno czynniki polityczne, jak i ekonomiczne. Wśród czynników politycznych bardzo istotną rolę odegrało przystąpienie państw z Europy Środkowo-Wschodniej do Wspólnoty Europejskiej i w konsekwencji do Unii Europejskiej. Towarzyszyła temu liberalizacja rynku transportu lotniczego oraz związana z tym możliwość ekspansji przewoźników niskokosztowych (Dobruszkes, 2009; Pijet-Migoń, 2012; Bjelicic, 2013). W przypadku portów wschodniej części Niemiec (dawnej Niemieckiej Republiki Demokratycznej) głównym czynnikiem rozwoju było zjednoczenie Niemiec. Do kluczowych czynników ekonomicznych należało otwarcie rynków pracy, rozwój gospodarczy, wzrost dochodów oraz mobilności mieszkańców (Hawlena, 2012a). Zmiany rynku lotniczego charakteryzowały się różną dynamiką w poszczególnych krajach. W przypadku wielu portów regionalnych można mówić o ich dynamicznym rozwoju, ale również można wskazać porty, w których ruch pasażerski jest obecnie na znacznie niższym poziomie niż oczekiwano.

Celem artykułu jest porównanie rozwoju portów regionalnych w byłych państwach bloku socjalistycznego Europy Środkowo-Wschodniej - Polsce, Czechach, Słowacji, Węgrzech, Rumunii, Bułgarii, Litwie, Łotwie i Estonii, w tym portów wschodniej części Niemiec, należących niegdyś do Niemieckiej Republiki Demokratycznej. W analizie nie uwzględniono natomiast Słowenii i Chorwacji, krajów będących częścią dawnej Jugosławii, która należała do bloku państw socjalistycznych, ale realizowała odrębną koncepcję rozwoju społeczno-ekonomicznego.

W pracy wykorzystano kilka metod badawczych - analizę danych statystycznych Eurostat, danych publikowanych przez porty lotnicze oraz urzędy lotnictwa cywilnego poszczególnych państw, analizę dokumentów planów rozwoju infrastruktury transportu lotniczego. Dodatkowo przeanalizowano aktualne oraz historyczne sieci połączeń z poszczególnych portów lotniczych na podstawie rozkładów lotów.

\section{Rynek lotniczy państw Europy Środkowo- Wschodniej przed akcesją do Unii Europejskiej}

Bezpośrednio po przemianach ustrojowych w tej części Europy - na początku lat 90. XX w. oraz w pierwszych latach XXI w. transport lotniczy zarówno w Polsce, jak i w pozostałych analizowanych krajach był znacznie mniej popularny niż w krajach Europy Zachodniej (Gabor, 2010; Pijet-Migoń, 2012). W 2003 r. zaledwie trzy porty (nie uwzględniając Berlina) w byłych krajach tzw. bloku socjalistycznego miały ruch pasażerski powyżej $5 \mathrm{mln}$. Były to lotniska stołeczne w Pradze, Budapeszcie i w Warszawie (ryc. 1). Tylko nieliczne porty regionalne obsługiwały rejsowy ruch międzynarodowy i były to głównie połączenia do portów hubowych we Frankfurcie, Monachium, Kopenhadze i Wiedniu. Zaledwie dwa porty regionalne - w Warnie i Burgas w Bułgarii, odnotowały ruch powyżej $1 \mathrm{mln}$, ale wiązało się to głównie z turystyką przyjazdową i popularnością kurortów nad Morzem Czarnym. Ruch pasażerski na tych lotniskach był na wysokim poziomie już w latach 70. XX w. (Papatheodorou, 2006; Ivanova, 2017). W pozostałych krajach tylko trzy lotniska regionalne miały ruch powyżej 300 tys. Dotyczyło to lotnisk w Krakowie (593 tys. pasażerów w 2003 r.), Gdańsku (364 tys.) i w Timişoarze (ok. 320 tys.).

Nieco inaczej wyglądał rynek lotniczy we wschodniej części Niemiec, gdzie w dwóch portach regionalnych ruch pasażerski w 2003 r. znacznie przekraczał jeden milion - były to lotniska Lipsk-Halle (1 mln 955 tys. pasażerów) i Drezno (1 mln 560 tys.). W trzecim co do wielkości porcie regionalnym - Erfurcie, liczba pasażerów wyniosła w 2003 r. 565 tys.

\section{Główne kierunki zmian}

Liberalizacja rynku transportu lotniczego i przyjęcie polityki „otwartego nieba” umożliwiły każdemu z przewoźników zarejestrowanych w dowolnym państwie Europejskiej Wspólnoty Gospodarczej na otwieranie połączeń na dowolnej trasie za dowolną cenę i z dowolną częstotliwością, przy zachowaniu praw do wolnej konkurencji (Polkowska, 2004; Hawlena, 2012b). Nowe prawo lotnicze umożliwiło ekspansję przewoźników działających już wcześniej w Europie Zachodniej i rozpoczęcie oferowania połączeń na nowych trasach, ale nowe przedsiębiorstwa lotnicze, najczęściej o niskokosztowym modelu działania (Low Cost Carriers, w skrócie określane jako LCC), zaczęły powstawać w nowych państwach unijnych (Bjelicic, 2007; Gabor, 2010). Do najbardziej znanych przewoźników niskokosztowych, utworzonych w tej części 

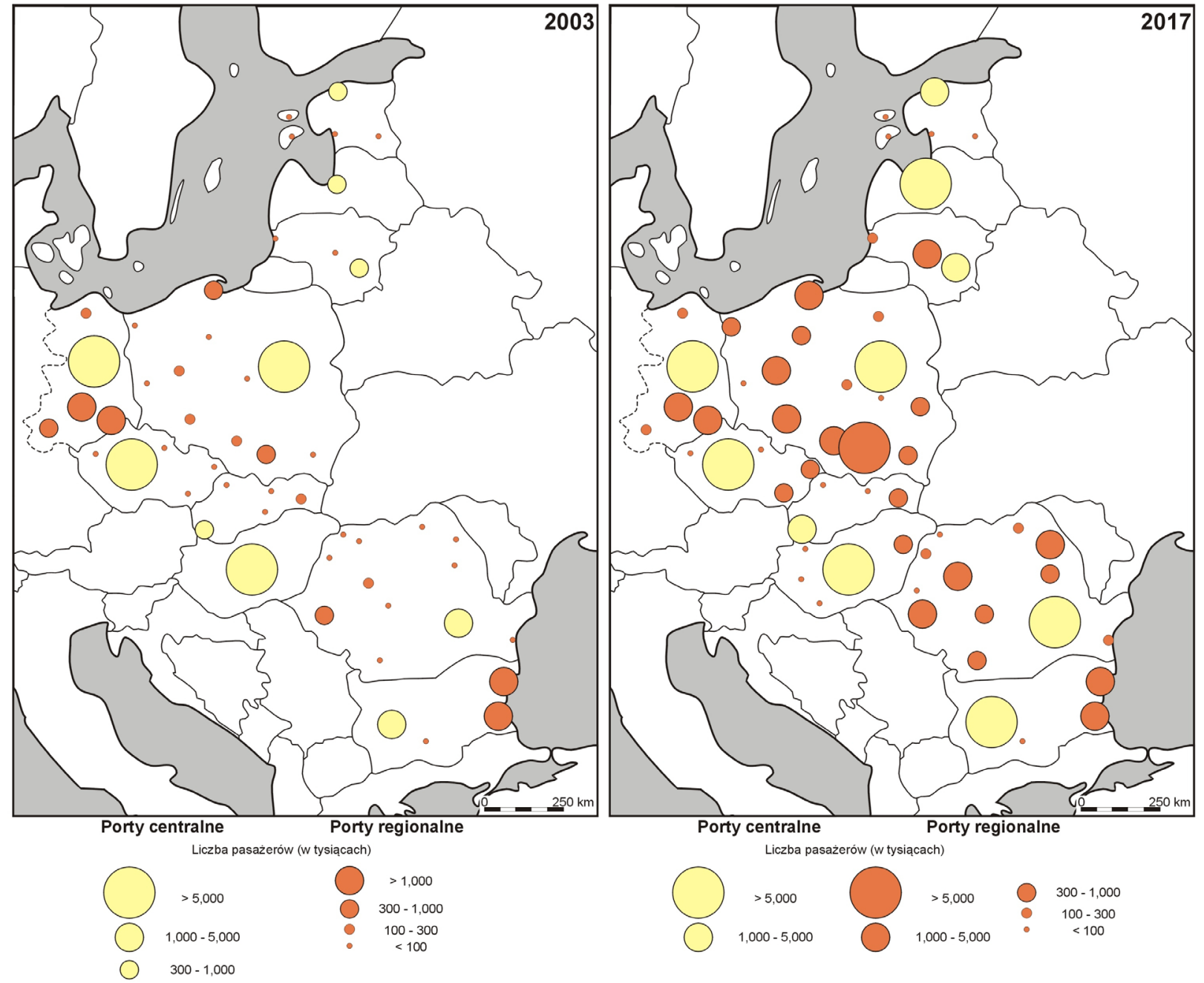

Ryc. 1. Wielkość ruchu pasażerskiego w portach lotniczych państw Europy Środkowo-Wschodniej z podziałałem na porty centralne i regionalne w 2003 i 2017 r.

Źródło: opracowanie własne na podstawie danych Eurostatu.

Europy, należały linie Air Polonia, Sky Europe, Wizzair, Centralwings, Blue Air'. Nie wszystkim tym przedsiębiorstwom udało się jednak przetrwać na bardzo konkurencyjnym rynku - linie Air Polonia i Sky Europe ogłosiły bankructwo, a linie Centralwings zakończyły działalność i zostały włączone w struktury PLL LOT. Niskokosztowy model działalności przewoźników lotniczych został szczegółowo opisany w pracy autorki (Pijet-Migoń, 2012).

Linie niskokosztowe zgodnie ze swoim modelem działania wybierały głównie tańsze i mniej zatłoczone porty regionalne, oferujące znacznie niższe ceny

\footnotetext{
Obecnie podział na linie niskokosztowe i linie tradycyjne jest nieostry, ponieważ model działalności zarówno jednej, jak i drugiej grupy przewoźników ewoluował. Niektóre linie lotnicze mają hybrydowy model działania. W artykule przyjęto podział na przewoźników tradycyjnych i niskokosztowych zgodnie z podziałem stosowanym przez Urząd Lotnictwa Cywilnego.
}

za usługi serwisowe oraz różnego rodzaju wsparcie, $w$ tym finansowe, w przypadku uruchomienia nowych połączeń (Dobruszkes, 2006; Gro $\beta$, Schröder, 2007; Trzepacz, 2007; Olipra, 2015). W pierwszych latach po akcesji do Unii Europejskiej, często w portach regionalnych odnotowano największą dynamikę wzrostu liczby pasażerów. Regularne połączenia międzynarodowe zaczęto oferować z portów, w których dawniej w ofercie były połączenia wyłącznie krajowe i ewentualnie czarterowe. O wzroście znaczenia portów regionalnych może świadczyć wzrost ich udziału w strukturze przewozów w poszczególnych krajach, przy czym dotyczyło to zwłaszcza państw o większym obszarze - Polski i Rumunii (tab. 1, ryc. 2). Już w 2008 r. liczba portów regionalnych w analizowanych nowych państwach unijnych wzrosła do 22, a siedem z nich obsłużyło ponad milion pasażerów. Były to porty lotnicze w Krakowie, Katowicach, Burgas, Gdańsku, Wrocławiu, Warnie i Poznaniu. Siedem portów znalazło się w przedziale pomiędzy 300 tys. 
a 1 mln pasażerów (Timişoara, Cluj-Napoca, Koszyce, Brno, Ostrawa, Łódź i Rzeszów) i osiem w przedziale pomiędzy 100 a 300 tys. (Szczecin, Bydgoszcz, laşi, Sibiu, Arad, Bacău, Palanga, Héviz-Balaton) (Pijet-Migoń, 2016). W 2017 r. liczba portów regionalnych, które obsługiwały powyżej 100 tys. pasażerów wzrosła do 28, w tym 11 odnotowało ruch pasażerski powyżej miliona (Kraków, Gdańsk, Katowice, Wrocław, Poznań, Kowno, Cluj-Napoca, laşi, Timişoara, Burgas i Warna).
Jednak jego wielkość była dość mocno zróżnicowana. Linie niskokosztowe w Słowacji w 2005 r. obsłużyły 65\% pasażerów, a w 2008 r. aż 90\%. W Polsce linie LCC osiągnęły ponad 50\% udziału w rynku przewozów w 2008 r., mniejszy udział miały w Rumunii - ok. 35\%. W znacznej mierze zależało to od kondycji dawnych przewoźników narodowych (flagowych) w poszczególnych krajach i ich zdolności do konkurowania z przedsiębiorstwami, które pojawiły się na rynku.

Tab. 1. Liczba portów regionalnych i ich udział strukturze przewozów w poszczególnych krajach.

\begin{tabular}{|c|c|c|c|c|c|}
\hline \multirow{2}{*}{ Kraj } & \multirow{2}{*}{$\begin{array}{l}\text { Liczba portów } \\
\text { regionalnych }\end{array}$} & \multicolumn{4}{|c|}{ Udział portów regionalnych w strukturze przewozów (\%) } \\
\hline & & 2003 r. & 2008 r. & 2013 r. & 2017 r. \\
\hline Polska & 13 & 27 & 54 & 56 & 53,3 \\
\hline Czechy & 4 & 5 & 7 & 7 & 6,3 \\
\hline Rumunia & 13 & 18,5 & 26 & 24 & 37 \\
\hline Węgry & 4 & poniżej 1 & 1,2 & 2 & 2,7 \\
\hline Bułgaria & 3 & 62 & 51 & 51 & 44 \\
\hline Łotwa & 0 & 0 & 0 & 0 & 0 \\
\hline Litwa & 2 & 9 & 20 & 24 & 28,3 \\
\hline Słowacja & 3 & 28 & 23 & 12 & 23,4 \\
\hline Estonia & 4 & 1 & 3 & 2 & 2 \\
\hline
\end{tabular}

Źródło: opracowanie własne na podstawie danych urzędów lotnictwa cywilnego oraz portów lotniczych.

Wśród przewoźników niskokosztowych sieć połączeń najbardziej rozbudowały linie Ryanair i Wizzair. Początkowo dominowały połączenia z portami brytyjskimi (Bjelicic, 2013), w przypadku Łotwy i Estonii dodatkowo z miastami skandynawskimi, a Rumunii z portami włoskimi i hiszpańskimi (Gabor, 2010). Było to odzwierciedleniem zapotrzebowania na podróże do najbardziej popularnych nowych rynków pracy i późniejszych odwiedzin rodzin i znajomych (Burrell, 2010). Z czasem sieć połączeń z portów regionalnych rozszerzano o nowe trasy, które wskazywały dodatkowo na główne kierunki współpracy gospodarczej, popyt turystyczny na tradycyjne destynacje (Hawlena, 2012b), jak i zainteresowanie nowymi kierunkami turystycznymi, zwłaszcza na potrzeby rozwijającej się turystyki krótkoterminowej typu city breaks (Groß, Schröder, 2007). Od 2016 r. wyraźnie wzrasta liczba połączeń do portów państw Partnerstwa Wschodniego, a zwłaszcza Gruzji i Ukrainy, które częściowo zliberalizowały rynek lotniczy, umożliwiając rozpoczęcie działalności przewoźnikom niskokosztowym (Beim, 2017).

Niskie ceny biletów oferowane przez linie niskokosztowe spowodowały, że zainteresowanie podróżami lotniczymi wyraźnie rosło. Linie niskokosztowe bardzo szybko osiągnęły znaczący udział w rynku przewozów lotniczych w analizowanych państwach.
Wzrost dostępności cenowej, a także znacznie większa oferta portów regionalnych bardzo szybko przyczyniła się do wzrostu liczby pasażerów. Dynamika wzrostu była szczególnie widoczna w pierwszych latach po przystąpieniu do Unii Europejskiej, a w ciągu kilkunastu lat po akcesji do Unii Europejskiej liczba pasażerów zwiększyła się wielokrotnie (ryc. 2), osiągając największe wartości w 2017 r. w Polsce (39 mln 972 tys. pasażerów), Rumunii (20 $\mathrm{m} \ln 271$ tys.), Czechach (16 mln 512 tys.), na Węgrzech (13 mln 458 tys.) i w Bułgarii (11 mln 535 tys.). Już w 2004 r. liczba pasażerów w Polsce wzrosła o 24\% w stosunku do roku poprzedniego, a na Słowacji aż o 72,7\%. W kolejnych latach dużą dynamiką - powyżej 30\% cechował się rynek państw nadbałtyckich (łotewski, estoński i litewski) oraz rumuński.

Tak istotne zmiany w liczbie podróżnych wymagały dużych zmian w infrastrukturze lotniczej. W przypadku wielu portów lotniczych zmieniła się ich forma własności. Udziałowcami bardzo często stały się władze lokalne, mocno zainteresowane rozwojem portu lotniczego, który zaczęto postrzegać jako czynnik stymulujący rozwój gospodarczy całego regionu (Marciszewska, Kaliński, 2009; Huderek-Glapska, Jankiewicz, 2011; Olipra, 2016; Pacner-Cybulska, Olipra, 2016; Tłoczyński, 2016). Rozbudowano i zmoderni- 


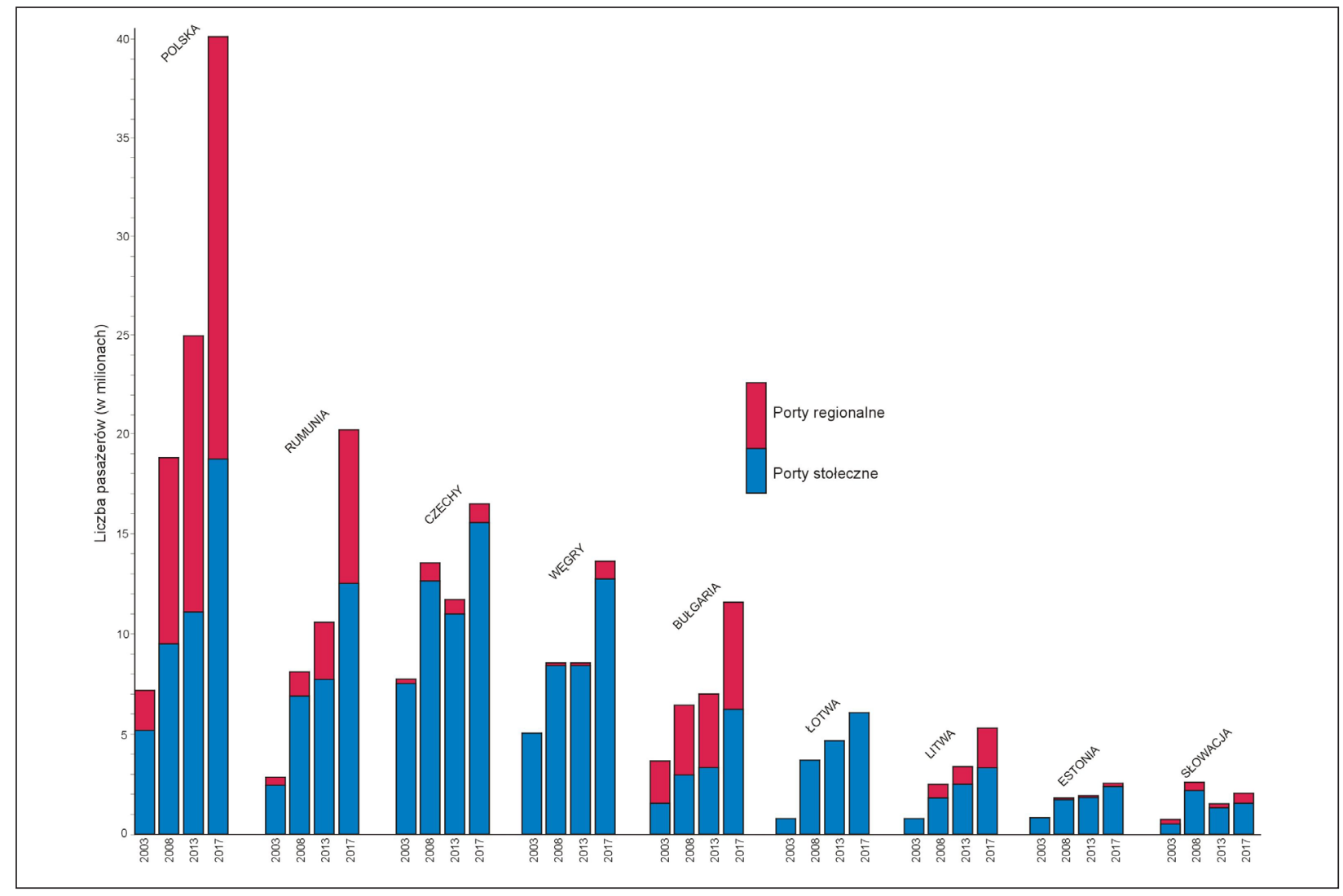

Ryc. 2. Wielkość ruchu pasażerskiego w analizowanych nowych państwach Unii Europejskiej w latach 2003, 2008, 2013 i 2017.

Źródło: opracowanie własne na podstawie danych Eurostatu.

zowano infrastrukturę w wielu portach lotniczych. Nowoczesne terminale wybudowano m.in. w Brnie, Pardubicach, Wrocławiu, Katowicach, Gdańsku, Rzeszowie i w Kownie. W Krakowie i w Gdańsku do terminali lotniczych doprowadzono połączenia kolejowe.

\section{Porty regionalne na badanym obszarze}

Do rozwoju portów regionalnych w większości przypadków przyczyniły się linie niskokosztowe, które zgodnie ze swoim modelem działania preferują tańsze i mniej zatłoczone porty lotnicze (Dobruszkes, 2009). Nie bez znaczenia było też zainteresowanie zarządów portów regionalnych i władz lokalnych pozyskaniem nowych połączeń, co często przekładało się na wsparcie różnego typu dla przewoźników w zamian za uruchomienie połączenia (Olipra, 2015).

Szczególnie dynamicznie rozwijały się porty regionalne w Polsce i w Rumunii (Jankiewicz, Huderek-Glapska, 2016) (tab. 1). Było to niewątpliwie związane $z$ wielkością tych państw i dużym oddaleniem wielu portów regionalnych od portu centralnego oraz stosunkowo słabo rozwiniętą siecią autostrad i szybkich połączeń kolejowych.

\subsection{Porty regionalne w Polsce}

W 2003 r., tuż przed rozszerzeniem Unii Europejskiej, w Polsce funkcjonowało 10 portów regionalnych, w tym pięć z nich oferowało regularne połączenia międzynarodowe (Kraków, Gdańsk, Wrocław, Poznań, Katowice). Ruch międzynarodowy był skoncentrowany w porcie lotniczym Warszawa Okęcie, który w 2003 r. obsłużyło 73\% ogółu pasażerów korzystających z polskich portów. W kolejnych latach w wyniku rozwoju portów regionalnych udział portu centralnego w strukturze przewozów malał. W 2005 r. wynosił $62 \%$, a w 2007 r. po raz pierwszy w historii spadł poniżej 50\%.

W 2017 r. funkcjonowało w Polsce 13 regionalnych portów lotniczych. Nowe porty zostały oddane do użytkowania w Lublinie (w grudniu 2012 r.), Radomiu ${ }^{2}$ (w maju 2014 r.) i Olsztynie - port pod nazwą Olsztyn-Mazury (w 2016 r.). W lipcu 2012 r. został oddany

2 Port lotniczy w Radomiu został oficjalnie oddany do użytkowania w maju 2014 r., ale pierwsze połączenia regularne linii Sprint Air zostały uruchomione 18 kwietnia 2016 r. Od 30 października 2018 r. z Radomia nie odbywają się loty rozkładowe. 
do użytku cywilnego port lotniczy w Modlinie jako lotnisko niskokosztowe dla aglomeracji warszawskiej i uzupełniające dla portu Warszawa Okęcie.

Po akcesji do Unii Europejskiej wszystkie porty z wyjątkiem Zielonej Góry oferowały połączenia międzynarodowe. Znacząco wzrosła liczba miast, z którymi Polska miała bezpośrednie połączenia. O szczególnej roli przewoźników niskokosztowych w rozwoju portów regionalnych może świadczyć ich udział w strukturze przewozów. Już w 2005 r. przewoźnicy niskokosztowi obsługiwali ponad 50\% pasażerów w Krakowie (52,75\%), Katowicach (82,4\%), Bydgoszczy (87\%) i Łodzi (98\%). Linie niskokosztowe zdominowały ruch także w nowych portach - w Lublinie, Modlinie oraz w porcie Olsztyn-Mazury.

Analizując zmiany rynku lotniczego po liberalizacji można wyróżnić trzy fazy jego rozwoju (Pijet-Migoń, 2016). Faza pierwsza, obejmująca lata 2004-2008, cechowała się bardzo dużą dynamiką wzrostu liczby pasażerów i ekspansją przewoźników niskokosztowych. Linie te $w$ tym okresie otwierały połączenia głównie z portów regionalnych. W tym czasie zapadły decyzje o rozbudowie i modernizacji infrastruktury lotniczej. Faza ta cechowała się równocześnie dużą niestabilnością sieci połączeń. Wiele nowych tras było otwieranych i przy niewystarczającym zainteresowaniu lub zbyt drapieżnej konkurencji ze strony innych przewoźników, bardzo szybko zamykanych.
W drugiej fazie, która przypadła mniej więcej na lata 2009-2010, i na którą dodatkowo nałożył się kryzys ekonomiczny w Europie Zachodniej oraz spowolnienie gospodarcze w Polsce, wzrost liczby pasażerów nie był już tak gwałtowny, a w przypadku niektórych portów zanotowano nawet spadek liczby pasażerów. W wyniku bardzo ostrej konkurencji cenowej nie wszystkie połączenia okazały się rentowne i część z nich zamykano. Zmniejszyła się zarówno liczba tras z wielu portów regionalnych, jak i liczba przewoźników oferujących połączenia z danego portu (ryc. 3). Zjawisko to zostało pogłębione przez problemy mniejszych i średniej wielkości przewoźników. Rozpoczął się proces konsolidacji rynku.

Trzecia faza to czas dalszej konsolidacji rynku. W wielu portach regionalnych pozycję lidera, a w mniejszych nawet monopolisty, zyskały linie Ryanair. Doszło do wyraźnego podziału na porty regionalne większe, w których ruch pasażerski wynosi ponad 500 tys. w skali roku i nadal dynamicznie rośnie oraz mniejsze, które borykają się z problemami finansowymi oraz mniejszą i zmienną liczbą pasażerów.

O sukcesach można mówić z pewnością w przypadku największych portów regionalnych. Port w Krakowie w 2017 r. obsłużył ponad 5 mln 829 tys. pasażerów, co sprawiło, że znacząco zmieniła się jego pozycja w hierarchii portów lotniczych w Europie. Bardzo dynamicznie rozwinął się również port

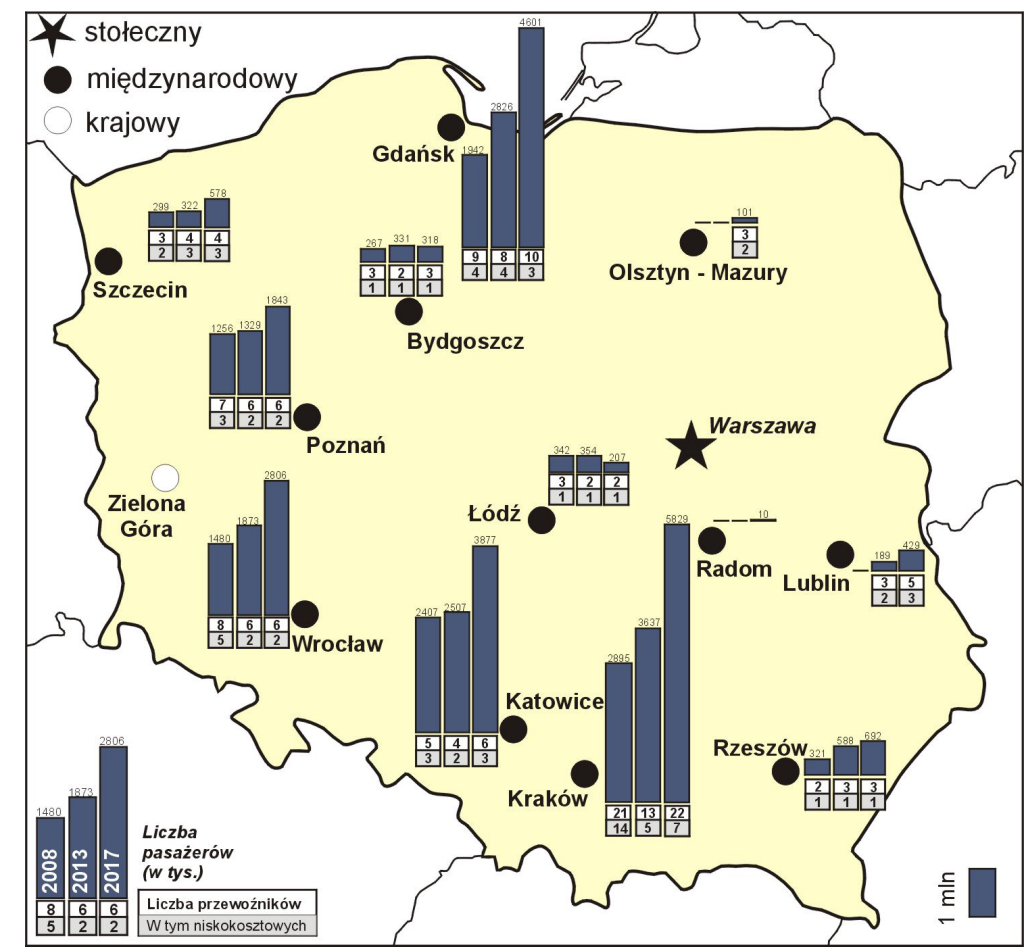

Ryc. 3. Liczba pasażerów oraz przewoźników, w tym niskokosztowych w polskich portach regionalnych w latach 2008 , 2013, 2017. 
w Gdańsku (w 2017 r. obsłużył 4 mln 602 tys. pasażerów), Katowicach (3 mln 866 tys.) i Wrocławiu (2 mln 805 tys.). Mniej dynamicznie niż w porcie we Wrocławiu rosła liczba pasażerów w Poznaniu (1 mln 843 tys.), co może dziwić, ponieważ oba porty obsługują aglomeracje o zbliżonej wielkości. W przypadku Poznania widoczny jest jednak wpływ obszaru ciążenia portów berlińskich, posiadających bardzo rozbudowaną sieć połączeń oraz portu w Warszawie. Wpływ obszaru ciążenia portów berlińskich uwidacznia się również w przypadku portu w Szczecinie.

Do znaczącego spadku liczby pasażerów doszło w porcie lotniczym w Łodzi. Liczba pasażerów w 2017 r. wynosiła tylko 207 tys. W Bydgoszczy liczba pasażerów (ok. 300 tys.) pozostaje na tym samym poziomie od kilku lat. Nie udało się zwiększyć ruchu pasażerskiego w Zielonej Górze. Lotnisko to ma nadal ruch pasażerski na bardzo niskim poziomie (w 2017 r. obsłużyło 17128 pasażerów). O największym rozczarowaniu i błędnym prognozowaniu można mówić w przypadku portu lotniczego w Radomiu, gdzie w 2016 r., a więc w pierwszym roku funkcjonowania połączeń regularnych, liczba pasażerów wyniosła 8 965, w kolejnym 9903 osób. W lipcu 2018 r. port złożył wniosek o upadłość. Został sprzedany Państwowemu Przedsiębiorstwu Portu Lotnicze. Obecnie planowana jest jego rozbudowa na potrzeby utworzenia portu zapasowego dla Warszawy oraz przywrócenie połączeń w 2020 r. (Dybalski, 2018). Inną nieudaną inwestycją okazał się port w Gdyni Kosakowie, w przypadku którego 11 lutego 2014 r. zapadła decyzja Komisji Europejskiej, stwierdzająca nielegalność dotacji przyznanej spółce Port Lotniczy Gdynia Kosakowo. Uwzględniono w niej złamanie unijnych zasad pomocy państwa i wskazano na konieczność jej zwrotu. W dniu 7 maja 2014 r. Sąd Rejonowy w Gdańsku ogłosił upadłość likwidacyjną obiektu. W 2017 r. decyzja Komisji Europejskiej została uchylona, jednak władze Gdyni zrezygnowały z planów przeznaczenia portu dla linii regularnych, planując pozostanie tylko przy ruchu General Aviation (Jamroż, 2017).

\subsection{Porty regionalne w Rumunii}

W 2006 r., tuż przed przystąpieniem Rumunii do Unii Europejskiej, w państwie tym funkcjonowało aż 15 lotnisk obsługujących komercyjne połączenia rozkładowe. Były to lotniska: Bukareszt Otopeni, Timişoara, Bukareszt Băneasa, Cluj-Napoca, Constanta, Sibu, Bacău, Iaşi, Oradea, Satu Mare, Suceava, Baia Mare, Tărgu Mureş, Arad i Craiova (kolejność według liczby obsłużonych pasażerów). Jednak aż 74\% ogółu pasażerów korzystało z portu Henri Conanda (dawne Otopeni) w Bukareszcie. Lotnisko to obsługiwało głównie linie tradycyjne (z wyjątkiem takich przewoźników jak Aer Lingus, Easy Jet, Alpi Eagle, Clicair i Wing Jet). Lotniskiem niskokosztowym dla Bukaresztu zostało lotnisko Băneasa, wybrane przez Blue Air na swoją główną bazę. Oprócz tego przewoźnika połączenia z lotniska Băneasa oferowali: Germanwings, Myair, Oneair, Sky Europe i Wizzair. W siatce połączeń dominowały miasta włoskie - Mediolan, Rzym, Wenecja, Florencja, Bari, Bolonia, Neapol, Katania i Treviso.

Największym lotniskiem regionalnym w 2006 r. było lotnisko w Timişoarze, które obsłużyło 753 tys. pasażerów. Port ten został wybrany przez regionalnego przewoźnika Carpatair na swój główny hub. Z lotniska tego połączenia oferowały ponadto linie Austrian Airlines, Lufthansa, Malév, Tarom oraz przewoźnicy niskokosztowi Volare, Blue Air oraz Alpi Eagles. W kolejnych latach ruch pasażerski na lotnisku w Timişoarze wzrastał, osiągając 1,2 mln w 2011 r. Jednak część połączeń została zamknięta i liczba pasażerów zaczęła maleć. Sytuacja najbardziej pogorszyła się w 2013 r. (ryc. 4), kiedy zawieszono wszystkie połączenia linii Carpatair. Ruch pasażerski spadł do 757 tys. Od 2009 r. lotnisko jest obsługiwane przez linie Wizzair, które otworzyły tam swoją bazę i coraz bardziej umacniają pozycję na rynku.

Drugim lotniskiem regionalnym, które bardzo się rozwija jest Cluj-Napoca. W 2006 r. lotnisko to było obsługiwane przez linie Tarom, Carpatair i Austrian Airlines. Z jego usług skorzystało 244 tys. pasażerów. W kolejnych latach liczba pasażerów stale rosła, zwłaszcza po uruchomieniu bazy linii Wizzair. W 2010 r. liczba pasażerów przekroczyła milion, a w 2014 r. wynosiła 1,2 mln.

W 2014 r. powyżej 200 tys. pasażerów obsłużyły lotniska w Tărgu Mureş (343 tys.), Bacău (313 tys.), laşi (273 tys.) i Sibiu (215 tys.). Dodatkowo połączenia międzynarodowe oferowały lotniska: Constanta, Craiova i Arad.

Podobnie jak w przypadku polskich lotnisk regionalnych można zauważyć, że sieć połączeń z portów regionalnych jest stosunkowo mało stabilna. Niektóre połączenia zostały zawieszone w wyniku wycofania się lub bankructwa przewoźników, jednak te najbardziej popularne szybko są zastępowane przez inne przedsiębiorstwa lotnicze. Spośród przewoźników niskokosztowych sieć połączeń najbardziej rozbudował Wizzair, który w 2015 r. oferował oprócz lotów z portu stołecznego w Bukareszcie połączenia aż z ośmiu portów regionalnych.

W 2017 r. na terenie Rumunii ruch międzynarodowy był obsługiwany w dziesięciu portach (ryc. 4). Porty w Tărgu Mureş i Baia Mare zostały czasowo zamknięte na czas prac remontowych. Największy ruch odnotowano w porcie Cluj-Napoca $(2,7 \mathrm{mln})$, Timişoarze (1,6 mln) i laşi (1,4 mln). Powyżej 400 tys. pasażerów obsłużono na lotniskach w Sibiu (504 tys.), 


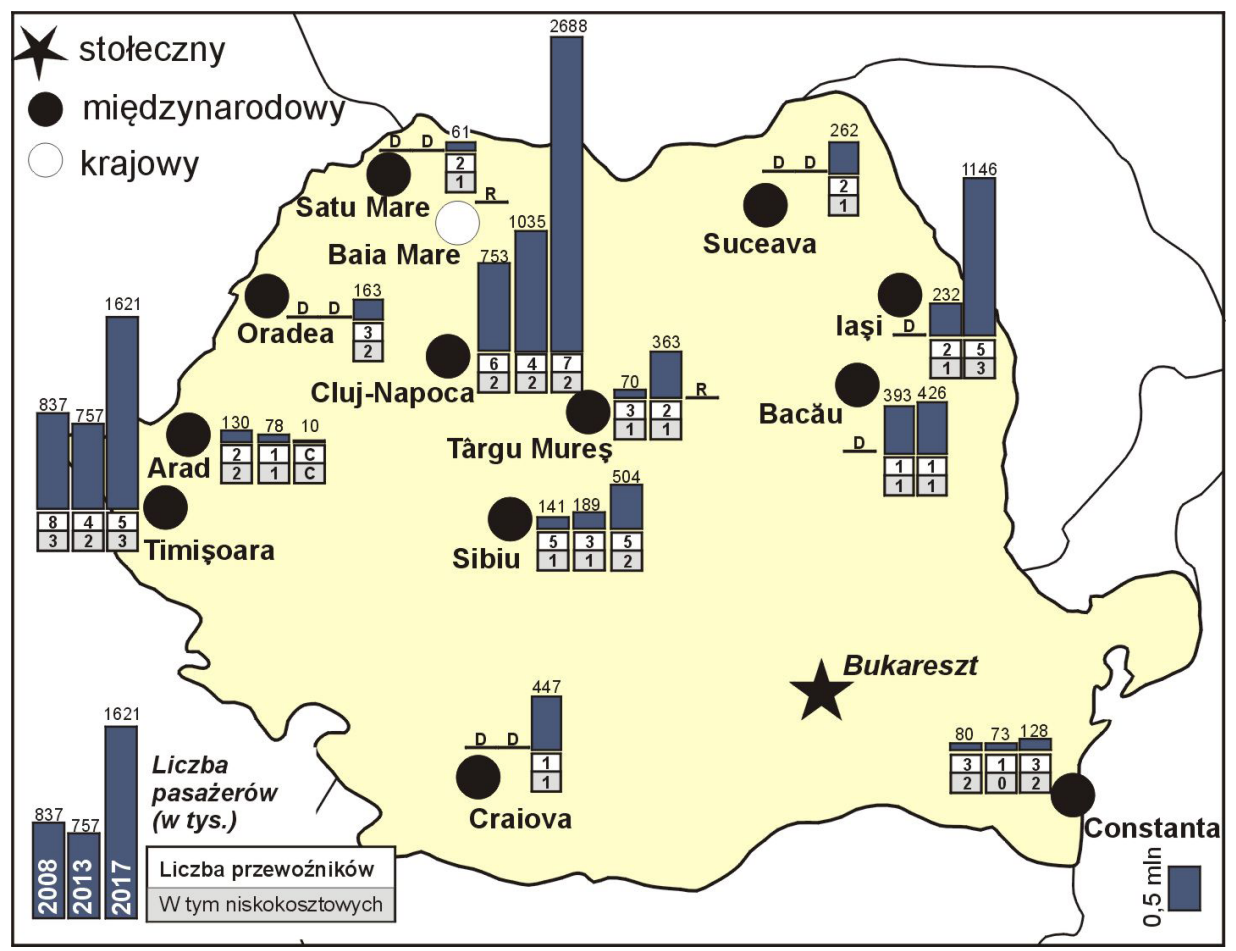

Ryc. 4. Liczba pasażerów oraz przewoźników, w tym niskokosztowych w rumuńskich portach regionalnych w latach 2008 , 2013, 2017.

Źródło: opracowanie własne na podstawie danych portów lotniczych i rozkładów lotów.

Craiova (447 tys.) i Bacău (426 tys.). Na bardzo niskim poziomie znajdował się ruch pasażerski na lotnisku Arad (ok. 11 tys. pasażerów). Lotnisko to nie obsługiwało połączeń regularnych, a wyłącznie ruch czarterowy i General Aviation. Można postrzegać to jako niepowodzenie portu, z którym wiązano duże szanse na rozwój ruchu pasażerskiego, zwłaszcza w 2008 r., kiedy linie Ryanair uruchomiły $z$ tego portu jedne z pierwszych połączeń niskosztowych w Rumunii (Pijet-Migoń, 2012).

\subsection{Porty regionalne w mniejszych państwach Europy Środkowo-Wschodniej}

\subsubsection{Porty regionalne w Czechach, Słowacji i na Węgrzech}

W pozostałych państwach omawianego regionu nie zaobserwowano aż tak dużych zmian w funkcjonowaniu portów regionalnych. Było to związane głównie z wielkością tych państw i stosunkowo małą odległością lub dogodnym dojazdem do głównych lotnisk.

Wśród czeskich portów regionalnych najwięcej pasażerów obsługuje lotnisko w Brnie (470 tys. w 2017 r.). Z tego lotniska połączenia w 2018 r. oferowały m.in. linie Ryanair, Fly BMI i Smart Wings. Rozwój portu lotniczego w Brnie jest trudny ze względu na bardzo silną konkurencję ze strony położonego w stosunkowo niewielkiej odległości portu lotniczego w Wiedniu, mającego znacznie bogatszą ofertę połączeń. Znacznie mniejszy ruch pasażerski występuje w pozostałych czeskich portach - w Ostrawie (324 tys.), Pardubicach (88 tys.) i Karlovych Varach (21 tys.). Lotniska te obsługiwane są głównie przez firmy czarterowe.

Tuż po akcesji do Unii Europejskiej dynamicznie rozwijało się lotnisko w Koszycach na Słowacji, osiągając maksymalne wartości przewozów (590 tys.) w 2008 r. Po bankructwie Sky Europe i wycofaniu się linii Ryanair liczba pasażerów w kolejnych latach spadała. W 2013 r. wynosiła 234 tys. W późniejszym czasie lotnisko zaczęło notować wzrosty liczby pasażerów, głównie za sprawą uruchomienia połączeń przez linię Wizzair, jednak były to już niższe wartości. W 2017 r. liczba obsłużonych pasażerów na tym lotnisku wynosiła 497 tys.

Na Węgrzech z portów regionalnych w 2017 r. najwięcej pasażerów obsłużyło lotnisko w Debreczynie (318 tys. pasażerów). Znacznie mniej pasażerów (poniżej 30 tys.) skorzystało z lotnisk w Héviz, Gyór i Szeged. Lotniska te były obsługiwane głównie przez połączenia czarterowe i sezonowe.

\subsubsection{Porty regionalne w państwach bałtyckich}

Na Litwie najbardziej rozwinęło się lotnisko regionalne w Kownie. Stało się to dzięki przewoźnikowi 
Ryanair, który rozpoczął obsługę połączeń z tego lotniska w 2005 r. i rozbudowywał ich sieć w kolejnych latach. W 2017 r. liczba pasażerów wyniosła $1 \mathrm{mln}$ 186 tys. Przez wiele lat linie Ryanair miały pozycję monopolisty na lotnisku w Kownie. W 2018 r. z tego portu połączenia oferowały także linie Wizzair oraz Nordica. Drugim lotniskiem regionalnym na Litwie, w którym ruch pasażerski znacząco wzrósł dzięki przewoźnikom niskokosztowym jest Palanga. W 2018 r. było ono obsługiwane m.in. przez linie Norwegian, Ryanair i Wizzair. Liczba pasażerów korzystających z tego lotniska wzrosła z 76 tys. w 2004 r. do 297 tys. w 2017 r.

Na Łotwie i w Estonii ruch lotniczy koncentruje się na lotniskach stołecznych w Rydze i Tallinie. W Estonii porty regionalne w Tartu, Kuressaare i Kärdla obsługują ruch poniżej 20 tys. w skali roku.

\subsubsection{Porty regionalne w Bułgarii}

W Bułgarii nadal wzrastał ruch pasażerski na lotniskach w Burgas i Warnie, przy czym w Burgas ruch pasażerski był znacząco wyższy (ryc. 5). W 2017 r. lotnisko to obsłużyło $2 \mathrm{mln} 982$ tys. pasażerów, natomiast lotnisko w Warnie - 1 mln 970 tys. Ruch na trzecim co do wielkości lotnisku regionalnym w Płowdiw w 2017 r. wynosił 91 tys. i z wyjątkiem połączenia ofe- rowanego przez linie Ryanair do Londynu Stansted lotnisko to obsługiwało wyłącznie ruch czarterowy.

\subsection{Porty regionalne we wschodniej części Niemiec}

W latach 80. XX w. regularny ruch pasażerski w Niemieckiej Republice Demokratycznej odbywał się głównie z berlińskiego lotniska Schönefeld. Ruch na pozostałych lotniskach był na stosunkowo niskim poziomie i obejmował głównie połączenia krajowe linii Interflug z Berlina Schönefeld do portów regionalnych - Erfurtu, Lipska, Drezna, a w latach 70. XX w. do położonego w sąsiedztwie kurortów nadbałtyckich Heringsdorf na wyspie Uznam. Okresowo linie Interflug oferowały połączenia międzynarodowe z Drezna do Budapesztu i Moskwy oraz z Lipska do Budapesztu.

Sytuacja znacząco zmieniła się po zjednoczeniu Niemiec, kiedy zaczęły się rozwijać także porty regionalne. Rozwój zawdzięczały zwiększeniu oferty przelotów czarterowych, organizowanych przez biura podróży, ale również otwieraniu nowych połączeń rejsowych, zarówno krajowych, jak i międzynarodowych. Ruch pasażerski w portach regionalnych wzrósł gwałtownie. W Lipsku w 1990 r. wynosił ok. 275 tys. pasażerów, po zjednoczeniu Niemiec wzrósł już

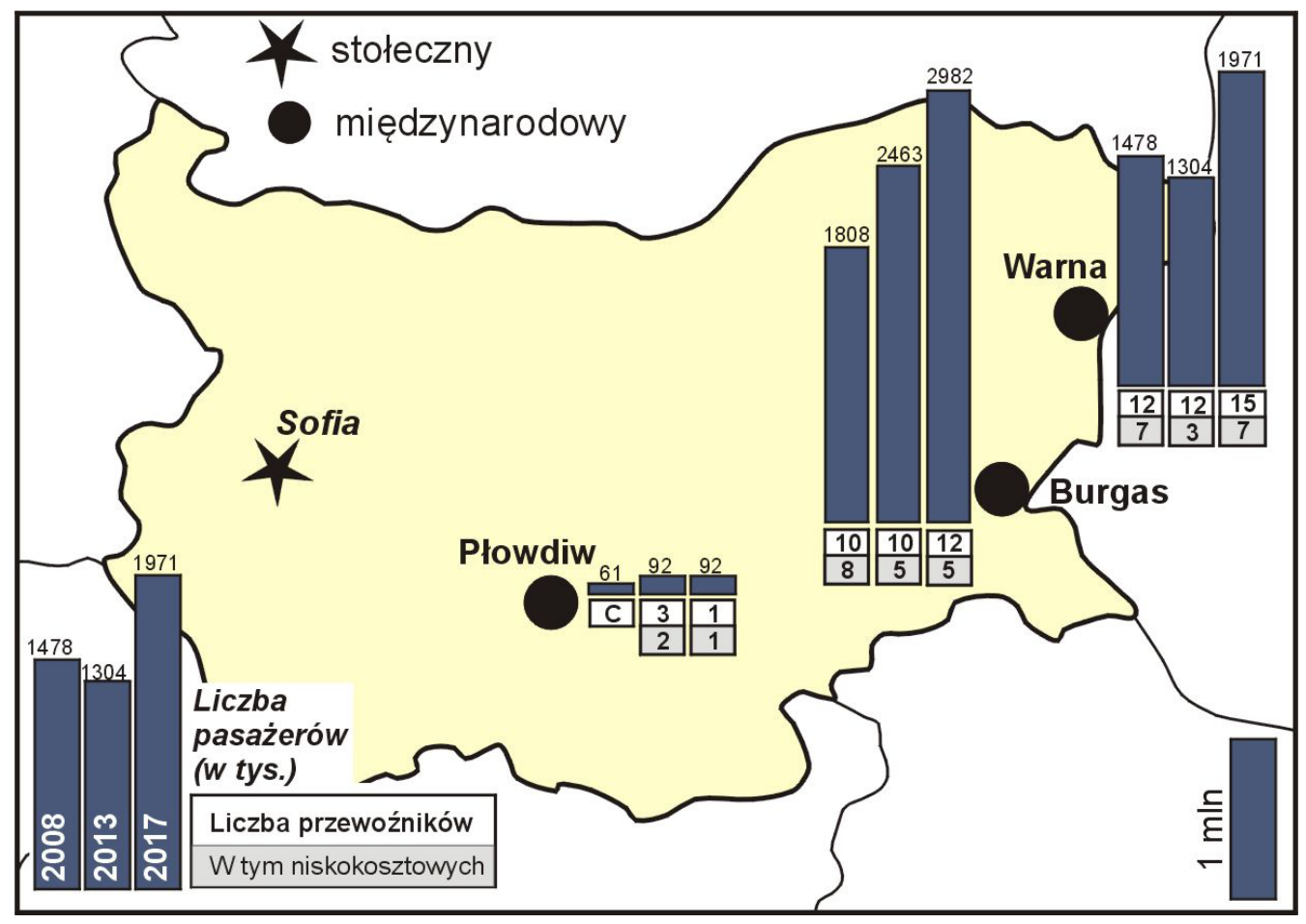

Ryc. 5. Liczba pasażerów oraz przewoźników, w tym niskokosztowych w bułgarskich portach regionalnych w latach 2008, 2013, 2017.

Źródło: opracowanie własne na podstawie danych portów lotniczych i rozkładów lotów. 
w 1992 r. do ponad 1 mln pasażerów. W przypadku Drezna w 1990 r. wynosił ok. 200 tys., w 1992 r. również przekroczył 1 mln, a w 1997 r. 1 mln 700 tys. Pełna liberalizacja transportu lotniczego w Unii Europejskiej w 1997 r. i wprowadzenie III pakietu liberalizacyjnego (obejmującego także prawo do pełnego kabotażu) (Szymajda, 2002) nie spowodowały już tak znaczących zmian. Ruch lotniczy w portach regionalnych nadal rósł, ale już nie tak gwałtownie. Rekordowe pod względem liczby pasażerów dla największych portów regionalnych w Lipsku i Dreźnie okazały się lata 20072009, po tym okresie ruch na tych lotniskach trochę zmniejszył się (ryc. 6).

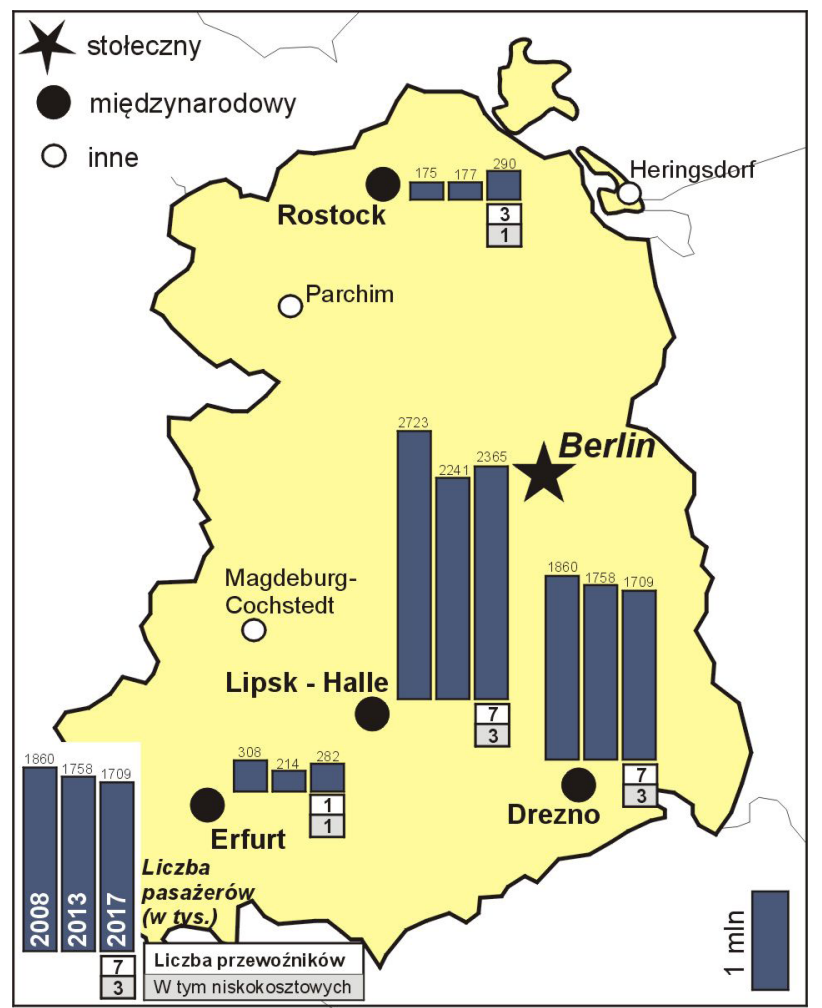

Ryc. 6. Liczba pasażerów w portach regionalnych wschodniej części Niemiec - dawnej Niemieckiej Republiki Demokratycznej w latach 2008, 2013, 2017.

Źródło: opracowanie własne na podstawie danych portów lotniczych i rozkładów lotów.

W 2017 r. najwięcej pasażerów obsłużyły lotniska Lipsk-Halle (2 mln 365 tys.) i Drezno (1 mln 709 tys.). Port lotniczy w Lipsku dodatkowo specjalizuje się w obsłudze połączeń cargo. Znacznie mniejszy ruch pasażerski był na lotniskach w Rostocku (291 tys.) i w Erfurcie (283 tys.). Nie udały się próby aktywizacji portu w Magdeburgu-Cochstedt, z którego w latach 2011-2013 linie Ryanair oferowały połączenia na trzech trasach. We wrześniu 2016 r. lotnisko zostało zamknięte. W porcie lotniczym w Parchim próbowano rozwinąć funkcję transportu towarowego, ale działania te nie powiodły się. Aktualnie obsługuje ono tylko loty lotnictwa ogólnego (General Aviation). Lotnisko w Heringsdorf oferuje loty rozkładowe i czarterowe tylko w sezonie wakacyjnym. Sieć połączeń z tego lotniska cechuje się dużą niestabilnością. Wiele tras było obsługiwanych bardzo krótko i następnie zawieszanych.

\section{Podsumowanie}

Zmiany polityczne i związane z nimi zmiany ekonomiczne bardzo wpłynęły na rozwój transportu lotniczego w Europie Środkowo-Wschodniej, zwłaszcza po rozszerzeniu Unii Europejskiej i liberalizacji rynku. Linie niskokosztowe przyczyniły się do rozwoju portów regionalnych, przy czym rozwój ten dotyczył obiektów położonych głównie w większych państwach. W przypadku wschodniej części Niemiec głównym czynnikiem zmian i wzrostu aktywności portów regionalnych było zjednoczenie NRD i RFN. Po pełnej liberalizacji rynku lotniczego w Europie Zachodniej, który miał miejsce prawie dziesięć lat wcześniej niż w Europie Środkowo-Wschodniej, zmiany liczby pasażerów w portach wschodniej części Niemiec nie były już tak znaczące.

Wzrost liczby pasażerów i prognozy dalszego rozwoju portów regionalnych położonych na omawianym obszarze skłoniły władze lokalne i rządy poszczególnych państw do podjęcia decyzji o ich rozbudowie i modernizacji. Równocześnie wzmocniło się przekonanie, że każdy port lotniczy przyczynia się do aktywizacji regionu, wpływając bezpośrednio lub pośrednio na jego gospodarczy rozwój. W przypadku kilku portów lotniczych niewłaściwie oceniono jednak popyt na transport lotniczy lub wpływ obszaru ciążenia portów już istniejących i posiadających atrakcyjną ofertę. Tak było np. w przypadku portu w Radomiu, Zielonej Górze czy w mniejszych niemieckich portach - Magdeburgu-Cochstedt i Parchim, które całkowicie zawiesiły działalność lub ruch pasażerski jest w nich śladowy. Poniżej oczekiwań okazał się ruch pasażerski na lotniskach położonych w pobliżu bardzo atrakcyjnych obszarów turystycznych - w Popradzie, leżącym u podnóża Tatr, Sármellek w pobliżu Balatonu i słynnego uzdrowiska w Héviz, w Karlovych Varach czy w Płowdiw u stóp Rodopów. Jednak sytuacja ta może się zmienić w przyszłości wraz z rozwojem oferty turystycznej tych regionów. Z portów średniej wielkości ruch poniżej oczekiwań charakteryzuje aktualnie Koszyce na Słowacji i Brno na Morawach oraz w Polsce - Łódź i Szczecin. W przypadku Brna, które posiada dogodne połączenie drogowe z Wiedniem, wyraźnie widać siłę oddziaływania dużego portu lotniczego w tej metropolii z bardzo rozbudowaną siecią połączeń.

O największym sukcesie można mówić w przypadku dużych portów regionalnych Polski i Rumunii, 
a zwłaszcza Krakowa, Gdańska, Katowic i Wrocławia oraz portów w Cluj-Napoca, Timişoarze, Iaşi. W mniejszych państwach znacząco wzrósł ruch pasażerski w Kownie, w Palandze, Debreczynie.

\section{Piśmiennictwo}

Beim M., 2107, Tak blisko, a tak daleko. Wyzwania wspótpracy transportowej między Uniq Europejska a krajami Partnerstwa Wschodniego, Raport, Ministerstwo Spraw Zagranicznych Rzeczypospolitej i Centrum Analiz Klubu Jagiellońskiego.

Bjelicic B., 2007, The business model of Low Cost Airlines - Past, present, future, [w:] Gro $\beta$ S., Schröder A. (red.), Handbook of Low Cost Airlines, Erich Schmidt Verlag, Berlin, 11-31.

Bjelicic B., 2013, Low Cost Carriers in Eastern Europe, [w:] Gross S., Lūck M. (red.), The Low Cost Carrier Worldwide, Ashgate, Farnham, 39-58.

Burrell K., 2010, Going steerage on Ryanair: culture of migrant air travel between Poland and the UK, Journal of Transport Geography, 19, 1023-1030.

Dobruszkes F., 2006, An analysis of European low-cost airlines and their networks, Journal of Transport Geography, 14, 240-264.

Dobruszkes F., 2009, New Europe, new low-cost services, Journal of Transport Geography, 17, 423-432.

Dybalski T., 2018, PPL przejmuje Port Lotniczy Radom, rozpoczyna się budowa nowego lotniska, Gazeta Wyborcza z dnia 13.10.2018.

Gabor D., 2010, Low-cost Airlines in Europe: Network Structures After the Enlargement of the European Union, Geographica Pannonica, 14(2), 49-58.

Gro $\beta$ S., Schröder A. (red.), 2007, Handbook of Low Cost Airlines, Erich Schmidt Verlag, Berlin.

Hawlena J., 2012a, Konkurencja na rynku lotniczych przewozów pasażerskich w warunkach globalizacji, Prace Naukowe Uniwersytetu Ekonomicznego w Katowicach, Katowice.

Hawlena J., 2012b, Rynek niskokosztowych przewozów lotniczych a rozwój sektora turystyki, Instytut Naukowo-Wydawniczy Spatium, Radom.

Huderek-Glapska S., Jankiewicz J., 2011, Miejsce i rola portów regionalnych na polskim rynku usług lotniczych, [w:] Rekowski M. (red.), Regionalne porty lotnicze w Polsce - charakterystyka i tendencje rozwojowe, Wydawnictwo Uniwersytetu Ekonomicznego w Poznaniu, Poznań, 107-131.

Ivanova M., 2017, Air transport-tourism nexus: A destination management perspective, Zangar, Varna.
Jamroż M., 2017, Wielki i kosztowny "sukces”, ale Gdynia nie chce już otwierać lotniska pasażerskiego, Gazeta Wyborcza z dnia 25.11.2017.

Jankiewicz J., Huderek-Glapska S., 2016, The air transport market in Central and Eastern Europe after a decade of liberalisation - Different paths of growth, Journal of Transport Geography, 50, 45-56.

Olipra Ł., 2015, Wspieranie połączeń tanich linii lotniczych ze środków publicznych, Studia Ekonomiczne, 209, Uniwersytet Ekonomiczny w Katowicach, 146-157.

Olipra Ł., 2016, Wpływ Portu Lotniczego Wrocław na gospodarkę miasta i regionu - szacowanie i analiza wydatków pasażerów, Studia Oeconomica Posnaniensia, 4, 7, 171-193.

Marciszewska E., Kaliński D., 2009, Port lotniczy jako czynnik rozwoju regionalnego, [w:] Barski A., Fabirkiewicz W., Jarosz Cz. (red.), Rozwój lotnictwa w regionach, Wydawnictwo Adam Marszałek, Toruń, 11-18.

Pacner-Cybulska E., Olipra Ł., 2016, Porty lotnicze jako strategiczny czynnik rozwoju Reginów w świetle regionalnych dokumentów programowych, Studia Oeconomica Posnaniensia, 4, 7, 127-150.

Papatheodorou A., 2006, Tourism and Air Transport Liberalisation in the Balkans, Bulgaria and Romania as Case Studies, conference paper, Second International Conference on Tourism Economics, Palma de Mallorca.

Pijet-Migoń E., 2012, Zmiany rynku lotniczych przewozów pasażerskich w Polsce po akcesji do Unii Europejskiej, Rozprawy Naukowe Instytutu Geografii i Rozwoju Regionalnego, 25, Uniwersytet Wrocławski, Wrocław.

Pijet-Migoń E., 2016, Etapy rozwoju regionalnych portów lotniczych w Polsce i innych państwach Europy Środkowo-Wschodniej po akcesji do Unii Europejskiej, Studia Oeconomica Posnaniensia, 4, 7, 30-58.

Polkowska M., 2004, Zasady tworzenia jednolitego europejskiego rynku usług lotniczych, Studia Europejskie, 4, Centrum Europejskie Uniwersytetu Warszawskiego, 49-68.

Szymajda I., 2002, Prawo lotnicze Unii Europejskiej - charakterystyka systemu, Studia Europejskie, 1(21), Centrum Europejskie Uniwersytetu Warszawskiego, 83-106.

Tłoczyński D., 2016, Konkurencja pomiędzy portami lotniczymi w Krakowie i Katowicach jako element rozwoju regionów, Studia Oeconomica Posnaniensia, 4, 7, 151170.

Trzepacz P., 2007, Spatial aspects of air transportation liberalization - changes in European airport hierarchy, Bulletin of Geography. Socio-Economic Series, 8, 163-177. 